\title{
Omega - 3 fatty acids in schizophrenia - part I: importance in the pathophysiology of schizophrenia
}

\author{
Kwasy tłuszczowe omega 3 w schizofrenii - część I: znaczenie w patofizjologii schizofrenii
}

$$
\text { Joanna Róg1 A,B,C,D,E,F, Hanna Karakuła-Juchnowicz }{ }^{2,3} \text { A,C,D,E }
$$

${ }^{1}$ Faculty of Human Nutrition and Consumer Sciences, Warsaw University of Life Sciences

2 I Department of Psychiatry, Psychotherapy and Early Intervention, Medical University of Lublin

3 Department of Clinical Neuropsychiatry, Medical University in Lublin

\begin{abstract}
Despite the increasing offer of antipsychotic drugs, the effectiveness of pharmacotherapy in schizophrenia is still unsatisfactory. Drug resistance, lack of complete remission and the increasing risk of metabolic complications are the reasons why the new forms of therapy in schizophrenia among which unsaturated essential fatty acids omega 3 (EFAs $\omega-3$ ) affecting the proper functioning of nervous system, are mentioned, are being looked for.

Fatty acids represent $50-60 \%$ of the dry weight of the brain and diet is one of the factors that influence the value of each of the fat fractions in the neuron membranes. Patients with schizophrenia tend to have irregular nutritional status concerning essential fatty acids $\omega-3$, which might result from metabolic disorders or irregular consumption of fatty acids.

Apart from being a review of the literature on this subject, this very paper characterizes essential fatty acids $\omega-3$, their metabolism, the most important sources in the diet and the opinions of experts in the field about the recommended intake. It pays attention to the role of essential fatty acids in both the structure and functioning of the central nervous system is, as well as their role in the pathophysiology of schizophrenia, with particular emphasis on the membrane concept by David Horrobin. The assessment of the errors in consumption and metabolism of essential fatty acids are described as well.

The evidence was found both in epidemiological and modeling studies. It supports the participation of EFAs in etiopathogenesis and pathophysiology of schizophrenia. Further research is needed, both observational and interventional, as to the role of essential fatty acids $\omega-3$ in the functioning of the CNS as well as the development and course of schizophrenia.
\end{abstract}

Keywords: schizophrenia, omega-3, essential fatty acids omega 3, docosahexaenoic acid, eicosapentaenoic acid, $\alpha$-linolenic acid, Horrobin theory, membrane theory of schizophrenia, central nervous system, niacin test

\section{Streszczenie}

Pomimo wprowadzenia na rynek kolejnych leków przeciwpsychotycznych, efektywność farmakoterapii w schizofrenii pozostaje nadal nie w pełni zadowalająca. Lekooporność, brak pełnej remisji oraz narastające ryzyko powikłań metabolicznych są powodem poszukiwań nowych form terapii w schizofrenii, wśród których wymienia się, oddziałujące na prawidłowe funkcjonowanie układu nerwowego, nienasycone kwasy tłuszczowe omega 3 (NNKT $\omega$-3).

Kwasy tłuszczowe stanowią 50-60\% suchej masy mózgu, a sposób żywienia stanowi jeden z czynników wpływających na stosunek poszczególnych frakcji tłuszczu w błonach neuronów. U pacjentów ze schizofrenią wykazano nieprawidłowy stan odżywienia NN KT $\omega-3$, który wynikać może z zaburzenia metabolizmu lub nieprawidłowej struktury spożycia kwasów tłuszczowych.

W artykule stanowiącym przegląd literatury dotyczącej tej tematyki scharakteryzowano NNKT $\omega-3$, ich metabolizm, najważniejsze źródła w diecie oraz stanowiska eksperckie w zakresie zalecanego spożycia. Przedstawiono rolę NNKT w budowie i funkcjonowaniu OUN oraz ich znaczenie w patofizjologii schizofrenii, ze szczególnym uwzględnieniem koncepcji błonowej Davida Horrobina. Opisano także możliwości oceny nieprawidłowości w spożyciu i metabolizmie NNKT.

Pochodzące z badań epidemiologicznych oraz modelowych dowody potwierdzają udział NNKT w etiopatogenezie i patofizjologii schizofrenii. Konieczne są dalsze badania, zarówno obserwacyjne, jak i interwencyjne dotyczące roli NNKT $\omega-3$ w funkcjonowaniu OUN oraz rozwoju i przebiegu schizofrenii.

Słowa kluczowe: schizofrenia, omega 3, niezbędne nienasycone kwasy tłuszczowe omega 3, kwas dokozaheksaenowy, kwas eikozapentaenowy, kwas $\alpha$-linolenowy, teoria Horrobina, teoria błonowa schizofrenii, ośrodkowy układ nerwowy, test niacynowy

\section{Introduction}

Antipsychotics (As) were introduced to the treatment of schizophrenia in the early 1960s. It was a major break- through in the treatment of this disorder [1]. With high incidence of extrapyramidal side effects that stigmatized patients, the first generation antipsychotics (FGAs) have been replaced by atypical antipsychotics (AAs). This contributed to 
the suppression of increasing cognitive impairment and reduction in the incidence of extrapyramidal complications of patients [2]. Despite the effectiveness of this group of drugs, in many cases the pharmacological therapy is not satisfactory enough. In addition, in many patients using AAs, an increased risk of metabolic complications such as obesity, type II diabetes, dyslipidemia and hypertension, is observed [3, 4]. The meta-analysis published in 2013 confirms that the use of AAs for up to 8 weeks of therapy is associated with weight gain from $3.45 \mathrm{~kg}$ (in case of olanzapine) to $0.94 \mathrm{~kg}$ (in case of aripiprazole) [5]. Metabolic consequences, achieving partial remissions or drug resistance are the reasons for the search for new forms of therapy in schizophrenia.

Authors mention the impact of diet over the course of many mental health problems among the areas of interest that may have some potentially practical significance $[6,7,8]$. Nutritional psychiatry is a rapidly growing field exploring the influence of diet over the development of mental illnesses and brain function $[9,10,11]$. The intensity of metabolic processes in the brain causes a high use of nutrients and energy. Both insufficient and excessive consumption, along with abnormal metabolism of exogenous substances could cause pathological conditions leading to dysfunction of CNS to occur [12]. Among the components, which are believed to have particular therapeutic properties, there are essential fatty acids omega-3 (EFAs $\omega-3)[13,14]$.

\section{Aim and method}

The authors of this paper aim at reviewing the available literature on the role of essential fatty acids omega 3 (EFAs $\omega$-3), with particular emphasis on docosahexaenoic acid (DHA) and eicosapentaenoic acid (EPA) in the development and course of schizophrenia.

Method: The authors made a review of the literature available on the topic. They used electronic databases like Medline and Google Scholar. The content they were looking for was dated: 2000 - August 2016, with the following keywords used: schizophrenia, omega-3, essential fatty acids omega 3 , docosahexaenoic acid, eicosapentaenoic acid, $\alpha$-linolenic acid, Horrobin theory, membrane theory of schizophrenia, central nervous system, niacin test.

Due to the complexity of the analyzed issue, the paper has been divided into the following sections:

1. Essential fatty acids omega 3

1.1. Structure

1.2. Metabolism

1.3. Sources, demand

2. Significance of EFAs in CNS

2.1. Metabolism of EFAs $\omega-3$ in CNS

2.2. Role of EFAs in the CNS structure

2.3. Role of EFAs in CNS functioning

3. Significance of EFAs $\omega-3$ for the development and the course of schizophrenia
3.1. Membrane concept by David Horrobin

3.2. Evidence to support the membrane concept from post-mortem examinations

3.3. Inflammatory theory and the membrane concept of schizophrenia

3.4. Fetal programming and the deficit of essential fatty acids $\omega-3$

4. The possibilities of measurement changes and consumption of essential fatty acids

4.1. Niacin test

4.2. The assessment of intake

4.3. Nutritional status

\section{Essential fatty acids omega 3}

\subsection{Structure}

Fatty acids $\omega$-3 belong to the family of essential fatty acids (EFAs) in the structure of which there is more than one double bond in the aliphatic carbon chain [15]. The presence of a double bond results in chemical properties of acids, including a high susceptibility to peroxidation. Aliphatic chain is formed by $18-22$ carbon molecules with methyl and acid groups at the chain ends. $\Omega-3$ group is characterized by the presence of the first double bond at the third carbon atom from the methyl end [15]. Among the major representatives of the $\omega-3$ family there are mentioned $\alpha$-linolenic acid (ALA) and eicosapentaenoic acid (EPA) and docosahexaenoic acid (DHA), which are of particular interest and source of investigations of researchers $[16,17]$.

\subsection{Metabolism}

Humans, similarly to other mammals, do not have the enzymes that would enable the synthesis of $\omega-3$ essential fatty acids de novo (i.e. occurring in the body metabolism of compounds to simpler EFAs $\omega$-3) [18]. One's diet should be the chief source of essential fatty acids. The sources of EPAs and DHAs in the human body may be either diet or metabolism of fatty acids taking place in the liver, involving elongases and delta5- and delta 6- desaturases $[19,20]$. The precursor of EPA and DHA fatty acid is $\alpha$-linolenic acid (ALA) [21] and the conversion is at low level, reaching about 2 to $10 \%$ [16]. Some authors suggest avalues not exceeding 1\% [22].

There are also other factors contributing to the intensity of ALA conversion. Among others, they include gender (higher levels of DHA and EPA synthesis of ALA were observed in females) [23], the intake of essential fatty acids [24], and the activity of enzymes involved in their metabolism [19]. The same proteins (desaturases) are involved in the metabolism of fatty acids $\omega-3$ and omega- $6(\omega-6)$. The human body does not have the ability to convert EFAs $\omega-6$ to $\omega-3$ and vice versa [25]. Consequently, the ratio of fatty acids belonging to two families, 
can lead to selective enzymatic reactions catalysis [26]. In the modern diet there is observed inadequate intake of essential fatty acids $\omega-3$ with significantly (even twenty times) higher intake of $\omega-6$ fatty acids [26, 27]. Desaturase activity and thus efficient synthesis of EPA and DHA is also affected by other hormonal and dietary factors [28]. Saturated fatty acids, trans-saturated fatty acids, cholesterol, glucocorticoids and adrenaline inhibit the activity of desaturase. Pyridoxine, zinc and magnesium as cofactors of desaturase 6 , are the factors required for normal activity of the enzyme. There are also different factors affecting the growth of desaturase 6, like insulin, low-fat diet and energy restrictions. Aging, oncogenic viruses, radiation, deficiency of protein and high intake of glucose, have inhibitory effect on the activity of the desaturase 6 [28].

\subsection{Sources, demand for EFAs $\omega-3$}

Sea food is very rich in EPA and DHA. The following fish are very rich in essential fatty acids $\omega-3$ (EPA + DHA $\mathrm{mg} / 100 \mathrm{mg}$ ): salmon- $2860 \mathrm{mg}$, trout $-2360 \mathrm{mg}$, mackerel -1 $750 \mathrm{mg}$, and herring-1 $290 \mathrm{mg}$ [29]. Table 1 shows the content of DHA, EPA and ALA in selected food products. The amount and the ratio between different types of fatty acids may be subject to significant fluctuations. The content of essential fatty acids in fish depends on the species of fish, the food consumed by fish food (sources of EPA and DHA are sea algae and phytoplankton), the season and fishing location [29]. ALA can also be found in vegetables, like flax seeds, oil of flax seeds, walnuts, and canola oil. The transformation of these products leads to EPA and DHA [30].

Experts have varied opinions about what on the recommended daily intake of essential fatty acids $\omega-3$, including EPA and DHA, should be. World Health Organization (WHO) recommends that the total amount of both acids be at the level 0.25-2 g / day [31]. According to experts of the European Food Safety Authority (EFSA) there is insufficient evidence to propose a mutual proportion for the essential fatty acids $\omega-3$ and $\omega-6$ in the diet [32]. The standard set by the EFSA standard for $\alpha$-linolenic acid (ALA) as the adequate intake (AI) amounts to $0.5 \%$ of the total energy value of the diet. In case of individuals aged over 18, 250 $\mathrm{mg} / \mathrm{d}$ is the recommended daily intake of EPA and DHA (Level of AI). Recommendations of National Food and Nutrition Institute (NFNI) for the consumption of various fractions of fats and the proportion between acids $\omega-3$ and $\omega-6$ are consistent with those proposed by EFSA [33]. According to the American Psychiatric Association (APA) eating fish two or more than two times a week is sufficient to provide a sufficient supply of essential fatty acids $\omega$-3. In case of impulsive patients, as well as those suffering from mood or psychotic disorders, APA recommends the total intake of EPA and DHA to be kept at the level of $1 \mathrm{~g} / \mathrm{d}$ [34]. To date, Polish Psychiatric Association have not provided any recommendations on the amount of essential fatty acids in the diet.

Table 1. The amount of acids: eicosapentaenoic acid (EPA), docosahexaenoic (DHA) and $\alpha$-linolenic acid (ALA) in selected foods

\begin{tabular}{|l|c|c|c|}
\hline & EPA & DHA & ALA \\
\hline Salmon & 0.71 & 2.15 & 0.55 \\
\hline Mackerel & 0.63 & 1.12 & 0.25 \\
\hline Rainbow trout & 0.60 & 1.76 & 0.15 \\
\hline Sardines & 0.90 & 0.10 & 0.10 \\
\hline Herring & 0.67 & 0.62 & 0.12 \\
\hline Tuna & 0.32 & 0.68 & 0.08 \\
\hline Eel & 0.26 & 0.58 & 0.66 \\
\hline Canola oil & 0 & 0 & 9.91 \\
\hline Walnuts & 0 & 0 & 6.57 \\
\hline Flax seeds & 0 & 0 & 16.60 \\
\hline
\end{tabular}

The amount provided as g / $100 \mathrm{~g}$ of product. Prepared on the basis of: The tables on the nutritional value of foods and dishes "by the authors: Kunachowicz H., Nadolna I., Przygoda B., Iwanow K. Wydanie III rozszerzone i uaktualnione, Instytut Żywności i Żywienia, Warszawa 2005.

\section{The importance of EFAs $\omega-3$ in the central nervous system (CNS)}

\subsection{Metabolism of EFAs $\omega-3$ in CNS}

Endogenous synthesis of EPA and DHA acids in the CNS is at a low level [35]. Fatty acids embedded in the neuronal membranes are transported from pooled plasma through the blood-brain barrier [36, 37]. Penetration of fatty acids takes place according with the concentration gradient (diffusion mechanism), although it seems likely that the conveyor system is involved (active transport mechanism) [38]. This means, the level of EPA and DHA in the CNS depends on the supply of individual fractions of dietary fatty acids and intensity of changes leading to synthesis in the liver. The half-life of DHA is 2 years, while the amount essential for normal functioning of the brain is estimated to be at the level of around 4 mg DHA per day [21]. EPA, after penetrating the blood-brain barrier, undergoes intense metabolic processes in which the transition to derivatives occurs [39].

In the CNS, the EFAs $\omega-3$ are transported to the cell membranes of neurons, where their esterification to phospholipids occurs. The release of fatty acids from membrane phospholipids takes place through enzymes phospholipases [21, 40]. The most intensive incorporation of essential fatty acids in the cell structures of the brain occurs primarily during the development of the CNS. Therefore, the perinatal period is a critical moment for the formation of the correct composition and the ratio of essential fatty acids in the brain. It has been shown, however, that changes in the metabolism or the type of dietary fat can change the proportions of fatty acids in the in CNS also during adulthood [41]. 


\subsection{The role of EFAs in the structure of CNS}

Fatty acids constitute about $50-60 \%$ of the dry weight of the brain. In the structure of neural cells polyunsaturated fatty acids predominate (approximately 35\% dry matter of the brain), mainly in the forms of belonging to the $\omega-6$ family arachidonic acid (AA) and docosahexaenoic acid (DHA) belonging to the family of $\omega-3$ [42].

A high content of DHA is a unique feature of neural cells and very few cells have that amount of DHA. There are some structures rich in DNA, like: cerebral cortex, synaptic membranes, mitochondria, retina of the eye and testicles $[43,44]$. The amount of EPA in the brain is in comparison to DHA about 250 - 300 times lower. Some minor differences between proportion of fatty acids are observed in the plasma, red blood cells, liver and heart (4- fold, 5-fold and 86-fold lower EPA level than DHA level) [45].

The low level of EPA in the CNS is suggested to be due to differences in the metabolism of individual lipid fractions in the brain and not due to selective transport of fatty acids [46]. The studies also looked at the process of $\beta$-oxidation, elongation and desaturation to docosapentaenoic acid (DPA) and a lower activity of transformations (recycling) of EPA in the CNS of rats [39].

\subsection{The role of EFAs in the functioning of CNS}

EFAs $\omega$-3 have pleiotropic effect on the structure of neurons. This is due to their role in regulating the expression of genes involved in physiological processes taking place in the brain [47]. The high content of essential fatty acids influences both the properties and functions of cell membranes of neurons, thus conditioning a proper interstructural communication. Membrane fluidity ensures conduction and transmission of nerve signal [48, 49]. EFAs $\omega-3$ facilitate maintaining the normal structure and integrity of cell membranes.These interactions affect indirectly the structures related to membranes (ion channels and receptors and transporters) [50, 51].

Among the roles of essential fatty acids $\omega-3$, participation in the neurogenesis and synaptogenesis processes, is listed. Authors noticed both the influence over growth (extension) and the ability to branching of neurites $[52,53]$ and the fusion of synapsins with synaptic vesicles was shown [53]. Synapsins are the specific for neurons proteins that are involved in the processes of synaptogenesis and synaptic maturation [54]. Essential fatty acids $\omega-3$ can contribute to an increase in the proliferation and differentiation of hippocampal cells $[52,53,55]$ which can reverse the decline of substances affecting neurogenesis process caused by aging [56]. DHA has a positive effect on the viability of neurons by inducing the formation of the neurotrophic factor BDNF [57] and own metabolic changes, in which it is metabolized to derivatives having neuroprotective activity - N-docosahexaenoylethanolamid (DEA) [58] and neuroprotectin D1 (NPD1) $[59,60]$.

Studies on animal models have also shown that the deficiency of essential fatty acids $\omega-3$ in the diet affects the metabolic disorders and the secretion of neurotransmitters [61]. EFAs have been shown to influence the regulation of metabolism of dopamine. In rats having the diet poor in fatty acids $\omega-3$, the increase in the concentration of dopamine and decrease in the concentration of its metabolites in the nucleus accumbens was observed, compared with the diet with optimal fatty acid content [62]. In turn, in the frontal cortex, the decrease in concentration was observed. Abnormal quantities of D1 and D2 receptors in the nucleus accumbens and frontal cortex, were also shown [63]. Acetylcholine [64] and serotonin [65] are also the monoamines, metabolism of which may be affected by EFAs $\omega-3$.

Due to an inadequate supply of fatty acids, serotonergic and cholinergic neurotransmission disorders occurred in the hippocampus of an animal model. There was a significant reduction in the basic secretion of acetylcholine and, in turn, after stimulation with $\mathrm{KCl}$, its release was significantly lower [64]. Deficiency of EFAs $\omega-3$ led to increased secretion of serotonin in basic mode and a decrease in its concentration after stimulation with fenfluramine [65].

\section{The importance of EFAs $\omega-3$ for development and course of schizophrenia}

\subsection{Membrane concept by David Horrobin}

In 1977, the membrane concept of schizophrenia development was formulated [66]. Although more than 40 years have passed since David Horrobin presented his theory, its foundations are still considered as an up-todate area of research on schizophrenia. In view of this hypothesis, the biochemical bases of mechanisms leading to the development of schizophrenia are changes in the content of phospholipids of cell membranes [66]. The structure of cell membranes depends on the interaction occurring between the genetic and environmental factors, and their abnormal structure may result from disorders of fatty acid metabolism [67]. The protein involved in the incorporation and release of lipids from the cellular structures is phospholipase A2 (PLA2). An abnormal expression of the gene encoding PLA2 would result in enzyme hyperactivity by running the cascade of reactions leading to the release of acids AA and DHA from the position Sn2 of phospholipids of cell membranes [68]. Also, a sufficient supply of EFAs in the diet has a significant impact on the proper structure of the membranes. Insufficient intake or improper proportion of the individual fractions of fatty acids may lead to the incorporation into cell membranes of monounsaturated and saturated fatty acids, thus interfering membrane functions [69]. 


\subsection{Evidence to support the membrane concept from post-mortem research}

Reports from the first experiments analyzing the post-mortem biochemical structures of CNS of patients with schizophrenia have confirmed the postulates of membrane theory. An analysis of the isolated postmortem material of 7 patients conducted in 1991 also showed significant differences in lipid composition of neurons compared to the control group [70].

Results of subsequent examinations there are some differences in fatty acid metabolism in brain regions of schizophrenic patients, as compared to controls. The observed biochemical changes were selective for the given areas of the CNS: in schizophrenic patients lower concentration of DHA in the orbitofrontal cortex [71] and in the prefrontal cortex [72], compared to the control group were observed. In the following brain areas: the hippocampus [73], the entorhinal cortex [74] and the frontal cortex [75] there were no DHA changes. It is possible that changes in the concentrations of individual fractions of fatty acids are secondary to changes in the concentrations of other lipid fractions, which makes interpretation of the results much more difficult [72]. Significantly lower levels of docosapentaenoic acid $\omega-6$ (DPA) and of AA acid in the hippocampus of schizophrenic patients were reported, as compared to the control group [73].

\subsection{Inflammatory theory and membrane concept of schizophrenia}

The role of deficiency or disorders of EFAs metabolism in the development of schizophrenia may also result from immunomodulatory properties of $\omega-3$ acids $[76,77]$. In schizophrenic individuals, abnormal functioning of the immune system and the presence of antibodies directed against the tissues of the brain structures were observed [78]. The activity of cytokines, microglia, astrocytes and immune cells developing in CNS inflammation was observed. Immunologic mechanisms allow the identification and inactivation of the harmful molecules for proper functioning of neurons. An excessive increase in the inflammatory activity in the CNS may result in disturbances in dopamingergic, serotonergic, noradrenergic and glutamatergic neurotransmission [79].

There are also other factors leading to dysfunction of defensive mechanisms: exposure and infection of the mother with organisms actuating immune response (toxoplasmosis, cytomegalovirus, chlamydia), dysfunction of the intestinal epithelium and its associated intestinal dysbiosis [80, 81].

An inadequate intake of immunomodulatory components is conducive to disturbed homeostasis of the immune system [82]. A chronic deficiency of EFAs $\omega-3$ activates the mechanisms that lead to the synthesis of cytokines (IL-6 and TNF-alpha), and C-reactive protein proinflammatory compounds [83]. The increased intake of $\omega-3$ was associated with higher levels of antiinflammatory IL-10, soluble receptor for IL- 6 and TGF- $\beta$ in the blood [84]. EFAs $\omega-3$ can also have a protective effect on behavioral changes and biochemical changes in the CNS of offspring of mothers with excessive immune response [85].

\subsection{Fetal programming and EFAs $\omega$-3 deficit}

In the study conducted in 1989, David Barker observed that the lower birth weight was associated with an increased risk of coronary heart disease in the future [86]. Observations of the British epidemiologist became the starting point for formulating a hypothesis of fetal programming. Exposure to adverse environmental factors in the prenatal period may result in permanent body metabolism changes. Adapting to the intrauterine conditions may increase the risk of many diseases during adulthood [86]. This hypothesis has been confirmed by retrospective observations on people born during the famine period in the Netherlands (years 1944-1945). Insufficient food intake among women who were giving during that period increased the risk of subsequent disorders of lipid and carbohydrate metabolism, coronary heart disease, and of schizophrenia [87, 88, 89].

The influence of fatty acids $\omega-3$ on fetal programming and the subsequent risk of schizophrenia are still unclear and require further analysis. Preliminary findings have shown that lower levels of DHA and AA of fetal tissues and lack of EFAs during breast-feeding were associated with abnormal development of the CNS later in life [90, 91]. However, the results of research conducted by Harper et al., suggest something else [92]. Women, whose children were suffering from schizophrenia spectrum disorders, had significantly higher levels of DHA in the blood in comparison to mothers who gave birth to healthy children. Possible explanation is the observation that a high intake of seafood increases the exposure to neurotoxic compounds (mercury, polychlorinated biphenyls PCBs) [93]. Disorders of the transport and transfer of fatty acids into the placenta could cause the observed increase of DHA levels in the serum [92].

\section{The possibility of measurement of changes and consumption of EFAs}

\subsection{Niacin test}

A niacin test is an easy-to-use method to check the regularity of cell membrane structures [94, 95, 96]. Niacin is a water-soluble B vitamin and a single oral application of a high dose is not associated with any health risks [97]. In subjects with normal response to oral administration of niacin due to expansion of blood vessels, there was ob- 
served erythema on the face with concomitant increased body temperature [98]. Currently, in the evaluation of the reaction of the organism there is applicable skin form of niacin test involving topical application of one drop of a solution of nicotinic acid methyl ester (AMN) with subsequent evaluation of the severity of skin reaction [94]. This method is quick, non-invasive and inexpensive. The mechanism of action of niacin is based on its ability to bind to receptors of skin macrophages and Langerhans cells in the epidermis. The cascade of reactions involves the activation of PLA2 and release from the cell membranes of AA. Activation of cyclooxygenase-2 (COX-2) leads to the synthesis of vasodilators prostaglandin D2 [95].

In schizophrenic patients, impaired or absent response, both in oral and dermal niacin test, were observed $[97,98,99]$. A decreased sensitivity to the effects of niacin was independent of both drug therapy [96, 100] and the consumption of coffee and alcohol [100]. The use of cannabis was associated with an abnormal reaction only in a group of healthy individuals [101]. Results of some tests suggest a negative correlation between the intensity of response to niacin and age and male sex [103, 104]. An impaired response was also observed in the relatives of schizophrenic patients [101]. A significantly lower sensitivity is characteristic for healthy individuals with a higher genetic load, compared to individuals in which only one member of the family was ill [105].

\subsection{Assessment of intake}

The assessment of intake allows the estimation of quantities of energy ingredients and nutritional supplements supplied, both at the individual and group levels [106]. To determine the intake of dietary EFAs $\omega-3$, previously validated questionnaires can be used (History of Nutrition [107] FFQ - Food Frequency Questionnaire [108]) and methods based on the identification of products consumed during the day (using the 24-hour recall, dietary record [109]). Each of the ways to assess consumption is burdened with the risk of either underestimation or overestimation of quantities of compounds supplied with the diet [110]. In order to calculate the individual components, nutritional value tables or special computer programs with built-in database nutritional products, are used [111].

The study of the nutritional value of certain diet can provide valuable information on the impact of nutrition on the course and severity of symptoms, and the correlation between the components supplied with the diet, and the subsequent risk of developing the disease. A negative correlation between the fish intake and the onset of mental disorders in the future, has been shown. Women who ate fish 3-4 times a week had 53\% (95\% CI: 0.30-0.69) lower risk of developing psychotic disorders, as compared to wom- en not consuming fish at all. Moderate amounts of EFAs $\omega-3$ $(0.21 \mathrm{~g} / \mathrm{d})$ in the diet caused a $24 \%$ reduction in the risk of psychosis as compared to low intake (0.14 g / d) [112].

The data on consumption of EFAs $\omega$-3 of patients with schizophrenia are ambiguous. A few studies suggest that patients suffering from schizophrenia consume smaller amounts of $\omega-3$ acids compared with healthy controls [113]. Results of other observations have shown that intake of EFAs is higher in individuals suffering from the illness; however, it results from the increased quantities of $\omega-6$ acids in the diet in comparison with healthy individuals. There were no differences in terms of the intake of $\omega-3$ EFAs between the groups of patients and controls [114]. A study conducted in Poland has shown that patients with schizophrenia consumed inadequate quantities of EFA (lower than the recommended) and the daily intake covered approximately $28 \%$ of the demand [115]. Disorders of cognitive function and lack of motivation resulting from health status can be a predictor of nutritional decisions and the diet deficient in nutrients [113]. In patients suffering from schizophrenia, there was a negative correlation between the intake of EFAs and the severity of the disease, regardless of drug therapy [116].

\subsection{Nutritional status}

The purpose of the assessment of nutritional status is to estimate the risk of nutrients deficiency. The nutritional status with a given component is affected by usual intake, metabolism and utilization in the body and pathological phenomena leading to disruption of these processes [117]. Biochemical analysis of blood can be the test to analyze the supply with fatty acids EPA and DHA [118]. The EFAs level in serum does not allow to estimate the long-term dietary intake, the amount reflects the current consumption. An indicator that better correlates with long-term intake of EFAs is the saturation with the individual factions of fats of cellular membranes of erythrocytes. Weaker dependencies in comparison to red blood cells, were also observed with regard to plasma [119].

A meta-analysis of 14 studies showed nutritional status with EFAs $\omega-3$ of patients suffering from schizophrenia dependent on drug therapy [120] . Patients who had not taken medication (medication-naive patients) and those treated with conventional agents had, compared to healthy individuals, significantly lower concentrations of arachidonic acid (AA), docosahexaenoic acid (DHA) and docosapentaenoic acid (DPA). In patients receiving conventional agents there were observed lower than in the control group levels of linoleic acid (LA), dihomo- $\gamma$ linolenic acid (DGLA), eicosapentaenoic acid (EPA) and docosatetraenoic acid (DTA). In patients treated with an atypical antypsychotics, decrease in the concentration of docosahexaenoic acid (DHA) was observed [120]. The 
meta-analysis published a year later confirmed the thesis of altered biochemical composition of erythrocyte membrane of schizophrenic patients [120]. Both in individuals not using pharmacotherapy as well as in those treated with antipsychotics, reduced levels to docosapentaenoic acid (DPA) and docosahexaenoic acid (DHA) and arachidonic acid (AA) were showed. The concentration of linoleic acid (LA) was lower only in the group of patients taking drugs.

It is postulated that poor dietary habits are not the only predictor of abnormal nutritional status with acids $\omega-3$ of patients [121]. The content of EFAs $\omega-3$ in the structures of the body is affected by,among others, sex, drugs [122], the course of treatment [123].

Earlier observations were focused on patients in the acute phase of the disease, coming from industrialized countries $[120,121]$. A study carried out in young, newly diagnosed patients provides results contrary to those achieved to date. [124]. Both the sick and their siblings reported higher levels of EFAs than individuals from the control group - docosahexaenoic acid (DHA), docosapentaenoic acid (DPA), arachidonic (AA), nervonoic acid (NA). The level of linoleic acid (LA) was significantly higher only in the group of siblings of people affected by the disease. The differences in test results can arise from the structure of the consumption of fatty acids. We observed higher levels of EFAs $\omega-3$ in patients with a lower BMI and the data on eating habits as well as consumption patterns of patients was limited [124].

\section{Summary}

The evidence from epidemiological studies and those conducted in animal models confirmed the likely impact of inadequate intake of EFAs and metabolic disorders in the development and course of schizophrenia. The differences in the results of the research presented and contrary to the results of observation can be due to the environment variables and genetic differences among the study groups. High methodological heterogeneity poses the necessity of conducting further well-designed research in this area [121]. Clarification of the exact role of EFAs in the pathophysiology of schizophrenia will allow for identifying the recommendations on the optimal intake of EFAs $\omega-3$ acids of patients. Thus, it may help to improve health status and reduce symptoms of the disease.

\section{Wstęp}

Wprowadzenie do leczenia schizofrenii na początku lat 60-tych leków przeciwpsychotycznych (LPP) było wielkim przełomem $\mathrm{w}$ terapii tego zaburzenia [1]. W związku z częstym występowaniem stygmatyzujących pacjentów objawów ubocznych ze strony układu pozapiramidowego, na przestrzeni lat obserwuje się zastępowanie leków przeciwpsychotycznych I generacji (LPP IG) lekami atypowymi (LPP II G). Przyczyniło się to do zahamowania narastających zaburzeń funkcji poznawczych oraz zmniejszenia częstości powikłań ze strony układu pozapiramidowego pacjentów [2]. Pomimo efektywności tej grupy leków, w wielu przypadkach farmakoterapia wydaje się być niedostatecznie zadowalająca, a dodatkowo u wielu pacjentów stosujących LPP IIG obserwuje się zwiększone ryzyko powikłań metabolicznych takich jak otyłość, cukrzyca typu II, zaburzenia gospodarki lipidowej oraz nadciśnienie tętnicze [3, 4] Opublikowana w 2013 roku metaanaliza wykazała, że stosowanie LPP IIG wiązało się $\mathrm{w}$ okresie do 8 tygodni terapii $\mathrm{z}$ przyrostem masy ciała rzędu od $3.45 \mathrm{~kg}$ (dla olanzapiny) do $0.94 \mathrm{~kg}$ (dla aripiprazolu) [5]. Konsekwencje metaboliczne, uzyskiwanie niepełnych remisji czy też lekooporność są powodem poszukiwań nowych form terapii w schizofrenii.

Wśród obszarów zainteresowań mogących mieć potencjalne znaczenie praktyczne wymienia się oddziaływania dietetyczne, które mogą modyfikować przebieg wielu schorzeń psychicznych $[6,7,8]$. Nutripsychiatria (ang. nutritional psychiatry) jest dynamicznie rozwijającą się dziedziną badającą wpływ diety na rozwój chorób psychicznych oraz funkcjonowanie mózgu [9, 10, 11]. Intensywność zachodzących w mózgu przemian metabolicznych powoduje wysokie wykorzystanie składników odżywczych i energetycznych. Niedostateczne lub nadmierne spożycie oraz nieprawidłowe przemiany substancji egzogennych mogłyby wpływać na występowanie stanów patologicznych prowadzących do zaburzeń pracy OUN [12]. Wśród składników, w których upatruje się szczególnych właściwości terapeutycznych wymienia się między innymi niezbędne nienasycone kwasy tłuszczowe omega 3 (NNKT $\omega-3)[13,14]$

\section{Cel i metoda}

Celem niniejszego artykułu jest przegląd literatury dotyczącej roli niezbędnych nienasyconych kwasów tłuszczowych (NNKT) z rodziny omega $3(\omega-3)$, ze szczególnym uwzględnieniem kwasów dokozaheksaenowego (DHA) i eikozapentaenowego (EPA), w rozwoju i przebiegu schizofrenii.

Metoda: Dokonano przeglądu dostępnych prac dotyczących poruszanej problematyki wykorzystując elektroniczne bazy danych Medline i Google Scholar, używając deskryptora czasowego 2000 - sierpień 2016 oraz słów-kluczy: schizofrenia, omega 3, niezbędne nienasycone kwasy tłuszczowe omega 3, kwas dokozaheksaenowy, kwas eikozapentaenowy, kwas $\alpha$-linolenowy, teoria Horrobina, 
teoria błonowa schizofrenii, ośrodkowy układ nerwowy, test niacynowy.

Ze względu na złożoność analizowanego zagadnienia, artykuł podzielono na następujące podrozdziały:

1. Niezbędne nienasycone kwasy tłuszczowe omega 3

1.1. Budowa

1.2. Metabolizm

1.3. Źródła, zapotrzebowanie

2. Znaczenie NNKT w OUN

2.1. Metabolizm NNKT $\omega-3$ w OUN

2.2. Rola NNKT $w$ budowie OUN

2.3. Rola NNKT w funkcjonowaniu OUN

3. Znaczenie NNKT $\omega$-3 dla rozwoju i przebiegu schizofrenii

3.1. Koncepcja błonowa Davida Horrobina

3.2. Dowody na słuszność koncepcji błonowej z badań post-mortem

3.3. Teoria zapalna a koncepcja błonowa schizofrenii

3.4. Programowanie płodowe a deficyt NNKT $\omega-3$

4. Możliwości pomiary przemian i spożycia NNKT

4.1. Test niacynowy

4.2. Ocena spożycia

4.3. Stan odżywienia

\section{Niezbędne nienasycone kwasy tłuszczowe omega 3}

\subsection{Budowa}

Kwasy tłuszczowe $\omega$-3 należą do rodziny niezbędnych nienasyconych kwasów tłuszczowych (NNKT), w których budowie występuje więcej niż jedno podwójne wiązanie w alifatycznym łańcuchu węglowym [15]. Z obecności podwójnego wiązania wynikają właściwości chemiczne kwasów, między innymi wysoka podatność na proces peroksydacji. Alifatyczny łańcuch buduje od 18 do 22 cząsteczek węgla, z grupami metylową i kwasową na końcach łańcucha. Rodzinę $\omega$-3 charakteryzuje obecność pierwszego wiązania podwójnego przy trzecim od metylowego końca atomie węgla [15]. Wśród głównych przedstawicieli rodziny $\omega-3$ wymienia się kwas $\alpha$-linolenowy (ALA) oraz stanowiące szczególne zainteresowanie i źródło dociekań badaczy kwas eikozapentaenowy (EPA) oraz kwas dokozaheksaenowy (DHA) [16, 17].

\subsection{Metabolizm}

Człowiek, podobnie jak inne ssaki, nie posiada enzymów, które umożliwiłyby syntezę NNKT $\omega$-3 de novo (czyli zachodzącej $\mathrm{w}$ organizmie przemiany związków prostszych do NNKT $\omega-3$ ) [18]. Zachodzi konieczność dostarczenia NNKT z dietą. Źródłami kwasów EPA i DHA $\mathrm{w}$ organizmie ludzkim może być pożywienie bądź zachodzące $\mathrm{w}$ wątrobie, $\mathrm{z}$ udziałem elongaz oraz delta5- i delta6desaturazy, przemiany kwasów tłuszczowych [19, 20]. Prekursorem kwasów EPA i DHA jest kwas $\alpha$-linolenowy
(ALA) [21], a konwersja kształtuje się niewielkim, sięgającym około 2 do 10\%, poziomie [16]. Niektórzy autorzy sugerują wartości nieprzekraczające 1\% [22].

Wśród czynników wpływających na intensywność przemiany ALA wymienia się między innymi płeć (wyższy poziom syntezy EPA i DHA z ALA obserwowano u kobiet) [23], spożycie NNKT [24] oraz aktywność enzymów uczestniczących w ich przemianach [19]. W metabolizm kwasów $\omega$-3 i omega $6(\omega-6)$ zaangażowane są te same białka (desaturazy). Organizm ludzki nie wykazuje zdolności do konwersji NNKT $\omega$-6 do $\omega$-3 i odwrotnie [25]. W konsekwencji stosunek kwasów tłuszczowych należących do obydwu rodzin może prowadzić do wybiórczej katalizy reakcji enzymatycznych [26]. We współczesnej diecie obserwuje się niedostateczne spożycie NNKT $\omega$-3 przy znamiennie (nawet dwudziestokrotnie) większym spożyciu kwasów $\omega-6$ [26, 27]. Na aktywność desaturaz, a więc efektywną syntezę EPA i DHA, wpływają także inne czynniki żywieniowe i hormonalne [28]. Nasycone kwasy tłuszczowe, izomery trans nasyconych kwasów tłuszczowych, cholesterol, adrenalina i glukokortykosteroidy hamują aktywność desaturaz. Pirydoksyna, cynk i magnez, jako kofaktory desaturazy 6, są czynnikami niezbędnymi dla prawidłowej aktywności enzymu. Wśród czynników wpływających na wzrost aktywności desaturazy 6 wymienia się także insulinę, dietę niskotłuszczową oraz restrykcje energetyczne. Hamujący wpływ na aktywność desaturazy 6 mają proces starzenia, onkogenne wirusy, radiacja, niedobór białka oraz wysokie spożycie glukozy [28].

\section{3 Źródła, zapotrzebowanie NNKT $\omega$-3}

Głównymi źródłami EPA i DHA jest żywność pochodzenia morskiego. Wśród ryb o wysokiej zawartości NNKT $\omega$-3 (mg EPA+DHA /100 mg produktu) wymienia się: łososia-2860 mg, pstrąga $-2360 \mathrm{mg}$, makrelę-1750 mg, śledzia-1290 mg oraz makrelę-1750 mg [29]. W tabeli nr 1 przedstawiono zawartość kwasów DHA, EPA i ALA w wybranych produktach spożywczych. Ilość oraz wzajemny stosunek poszczególnych rodzajów kwasów tłuszczowych ulegać może znacznym wahaniom. Zawartość NNKT w mięsie ryb zależy od gatunku ryby, spożywanego przez nią pożywienia (źródłami EPA i DHA są stanowiące pokarm zwierząt morskich algi oraz fitoplankton), pory roku i miejsca połowu [29]. Roślinnymi źródłami ALA, którego przemiany prowadzą do powstania EPA i DHA są siemię lniane i olej z jego nasion, orzechy włoskie oraz olej rzepakowy [30].

Stanowiska eksperckie w sprawie zalecanego dziennego spożycia NNKT $\omega-3$, w tym EPA i DHA, nie są jednoznaczne. Światowa Organizacja Zdrowa (WHO) zaleca by łączna ilość obydwu kwasów kształtowała się na poziomie 0,25-2 g/dobę [31]. Według ekspertów Europejskiego Urzędu ds. Żywności (EFSA) brakuje wystarczających dowodów dla zaproponowania wzajemnego stosunku dla 
NNKT $\omega-3$ i $\omega-6$ w diecie [32]. Ustalona przez EFSA norma dla kwasu $\alpha$-linolenowego (ALA) na poziomie wystarczającego spożycia (AI) wynosi $0,5 \%$ całkowitej wartości energetycznej diety. Dla osób powyżej 18 roku życia specjaliści rekomendują podaż $250 \mathrm{mg} / \mathrm{d}$ jako sumy EPA i DHA (poziom AI).

Rekomendacje Instytutu Żywności i Żywienia (IŻŻ) dotyczące spożycia poszczególnych frakcji tłuszczów oraz proporcji między kwasami $\omega-3$ i $\omega-6$ są zbieżne z zaproponowanymi przez EFSA [33]. Według American Psychiatric Association (APA) wystarczające dla zapewnienia optymalnej podaży NNKT $\omega-3$ jest spożywanie ryb dwa lub powyżej dwóch razy w tygodniu. Dla pacjentów cierpiących na zaburzenia nastroju, zaburzenia psychotyczne oraz pacjentów impulsywnych APA zaleca łączne spożycie EPA i DHA w ilości 1g/d [34]. Polskie Towarzystwo Psychiatryczne do chwili obecnej nie wydało rekomendacji dotyczących ilości NNKT w diecie.

Tabela 1. Zawartość kwasów: eikozapentaenowego (EPA), dokozaheksanowego (DHA) i $\alpha$-linolenowego (ALA) w wybranych produktach spożywczych

\begin{tabular}{|l|c|c|c|}
\hline & EPA & DHA & ALA \\
\hline Łosoś & 0,71 & 2,15 & 0,55 \\
\hline Makrela & 0,63 & 1,12 & 0,25 \\
\hline Pstrąg tęczowy & 0,60 & 1,76 & 0,15 \\
\hline Sardynki & 0,90 & 0,10 & 0,10 \\
\hline Śledź & 0,67 & 0,62 & 0,12 \\
\hline Tuńczyk & 0,32 & 0,68 & 0,08 \\
\hline Węgorz & 0,26 & 0,58 & 0,66 \\
\hline Olej rzepakowy & 0 & 0 & 9,91 \\
\hline Orzechy włoskie & 0 & 0 & 6,57 \\
\hline Siemię lniane & 0 & 0 & 16,60 \\
\hline
\end{tabular}

Ilość podana w g/100 g produktu. Przygotowano na podstawie: Tabele wartości odżywczej produktów spożywczych i potraw" autorów: Kunachowicz H., Nadolna I., Przygoda B., Iwanow K. Wydanie III rozszerzone i uaktualnione, Instytut Żywności i Żywienia, Warszawa 2005.

\section{Znacznie NNKT $\omega$-3 $w$ ośrodkowym układzie ner- wowym (OUN)}

\subsection{Metabolizm NNKT $\omega-3$ w OUN}

Endogenna synteza kwasów EPA i DHA w OUN kształtuje się na niskim poziomie [35]. Wbudowywane w błony neuronów kwasy tłuszczowe są transportowane z puli osocza za pośrednictwem bariery krew-mózg [36, 37]. Przenikanie kwasów tłuszczowych zachodzi zgodnie z gradientem stężeń (mechanizm dyfuzji), choć prawdopodobne wydaje się być także zaangażowanie systemu przenośników (mechanizm transportu aktywnego) [38]. Poziom EPA i DHA w OUN zależny jest więc od podaży z dietą poszczególnych frakcji kwasów tłuszczowych i intensywności przemian prowadzących do syntezy w wątrobie. Okres półtrwania DHA wynosi 2 lata, a ilość niezbędna dla prawidłowej funkcji mózgu szacowana jest na około $4 \mathrm{mg}$ DHA na dobę [21]. EPA, po przeniknięciu bariery krew-mózg ulega intensywnym procesom metabolicznym, w których następuję przemiana do pochodnych [39].

W OUN NNKT $\omega$-3 transportowane są do błon komórkowych neuronów, gdzie zachodzi ich estryfikacja do fosfolipidów. Uwalnianie kwasów tłuszczowych z fosfolipidów błonowych następuje za pośrednictwem enzymów - fosfolipaz [21, 40]. Najintensywniejsze wbudowywanie NNKT w struktury komórkowe mózgu zachodzi przede wszystkim w okresie rozwoju OUN. Okres okołoporodowy jest zatem momentem krytycznym dla kształtowania prawidłowego składu i stosunku NNKT w mózgu. Wykazano jednak, że zmiany w metabolizmie lub rodzaju spożywanego tłuszczu mogą zmieniać proporcje kwasów tłuszczowych OUN także w okresie dorosłości [41].

\subsection{Rola NNKT $w$ budowie OUN}

Kwasy tłuszczowe stanowią około 50-60 \% suchej masy mózgu. W strukturze komórek nerwowych przeważają wielonienasycone kwasy tłuszczowe (około 35\% suchej masy mózgu), głównie $w$ formach należącego do rodziny $\omega-6$ kwasu arachidonowego (AA) oraz należącego do rodziny $\omega$-3 kwasu dokozaheksaenowego (DHA) [42].

Wysoka zawartość DHA jest dla komórek nerwowych cechą unikatową, charakteryzują się nią nieliczne komórki. Wśród struktur bogatych w DHA wymienia się korę mózgową, błony komórkowe synaps, mitochondria, siatkówkę oka oraz jądra [43, 44]. Ilość EPA w mózgu jest w porównaniu do DHA około 250 - 300 -krotnie niższa. Mniejsze różnice między proporcją kwasów tłuszczowych obserwuje się w osoczu, krwinkach czerwonych, wątrobie i sercu (odpowiednio 4-krotnie, 5-krotnie, oraz 86-krotnie niższy poziom EPA niż DHA) [45]. Sugeruje się, że niewielka ilość EPA w OUN wynika z różnic w metabolizmie poszczególnych frakcji lipidów w mózgu, a nie z selektywnego transportu kwasów tłuszczowych [46]. W badaniach obserwowano proces $\beta$-oksydacji, elongację oraz desaturację do kwasu dokozapentaenowego (DPA) oraz niższą aktywność przemian (recykling) kwasu EPA w OUN szczurów [39].

\subsection{Rola NNKT w funkcjonowaniu OUN}

NNKT $\omega-3$ wykazują plejotropowe działanie na struktury neuronów. Wynika to z ich roli w regulacji ekspresji genów zaangażowanych w odbywające się w mózgu procesy fizjologiczne [47]. Wysoka zawartość NNKT wpływa na właściwości i funkcje błon komórkowych neuronów, warunkując prawidłową komunikację międzystrukturalną. Płynność błon zapewnia przewodzenie i transmisję sygnału nerwowego [48, 49]. NNKT $\omega-3$ umożliwiają utrzymanie prawidłowej struktury i integralności błon komórkowych. Oddziaływania te wpływają pośrednio także na struktury związane $\mathrm{z}$ membranami (kanały jonowe oraz receptory i transportery) [50, 51]. 
Wśród ról NNKT $\omega-3$ wymienia się udział $\mathrm{w}$ procesach neurogenezy i synaptogenezy. Wykazano wpływ na wzrost (wydłużanie) i zdolność do rozgałęziania neurytów [52, 53] oraz fuzję synapsyn $\mathrm{z}$ pęcherzykami synaptycznymi [53]. Synapsyny są białkami specyficznymi dla neuronów biorącymi udział w procesach synaptogenezy i dojrzewania synaps [54]. NNKT $\omega$-3 mogą wpływać na wzrost proliferacji i różnicowania komórek hipokampa [52, 53, 55] oraz odwracać spowodowany wiekiem spadek substancji oddziałujących na proces neurogenezy [56]. DHA wywiera korzystny efekt na żywotność neuronów poprzez indukcję powstawania czynnika neurotroficznego BDNF [57] oraz przemiany własne, w których metabolizowany jest do pochodnych o neuroprotekcyjnym działaniu - N-docosahexaenoylethanolamid (DEA) [58] oraz neuroprotektyny 1 (NPD1) [59, 60].

Badania na modelach zwierzęcych dowiodły także, że niedobory NNKT $\omega$-3 w diecie wpływają na zaburzenia metabolizmu i sekrecji neuroprzekaźników [61]. Wykazano wpływ NNKT w regulacji metabolizmu dopaminy.

U szczurów karmionych dietą deficytową w kwasy $\omega$-3 obserwowano wzrost stężenia dopaminy oraz spadek stężenia jej metabolitów w jądrze półleżącym w porównaniu z dietą o optymalnej zawartości kwasów tłuszczowych [62]. W korze czołowej obserwowano z kolei spadek stężenia. Wykazano także zaburzenia w ilości receptorów D2 i D1 w jądrze półleżącym oraz w korze czołowej [63]. Monoaminami, na których metabolizm wpływać mogą NNKT $\omega$-3 są także acetylocholina [64] i serotonina [65].

Na skutek niedostatecznej podaży kwasów tłuszczowych dochodziło do zaburzeń neurotransmisji cholinergicznej i serotoninergicznej w hipokampie w modelu zwierzęcym. Wykazano znamienną redukcję podstawowego wydzielania acetylocholiny, z kolei po stymulacji $\mathrm{KCl}$ jej uwalnianie było znamiennie niższe [64]. Niedobór NNKT $\omega-3$ prowadził do wzrostu sekrecji serotoniny w stanie podstawowym oraz spadku jej stężenia po stymulacji fenfluraminą [65].

\section{Znaczenie NNKT $\omega$-3 dla rozwoju i przebiegu schizo- frenii}

\subsection{Koncepcja błonowa Davida Horrobina}

W 1977 sformułowana została koncepcja błonowa rozwoju schizofrenii [66]. Chociaż od postulowanej przez Davida Horrobina teorii minęło ponad 40 lat, jej założenia stanowią wciąż aktualny obszar badań nad schizofrenią. W świetle hipotezy, podłożem biochemicznym mechanizmów prowadzących do rozwoju schizofrenii są zmiany w składzie fosfolipidów błon komórkowych [66]. Struktura membran komórkowych zależy od interakcji zachodzącymi między czynnikami genetycznymi oraz środowiskowymi, a ich nieprawidłowa budowa wynikać może z zaburzeń metabolizmu kwasów tłuszczowych [67]. Białkiem zaangażowanym we wbudowywanie i uwalnianie lipidów ze struktur komórkowych jest fosfolipaza A2 (PLA2). Nieprawidłowa ekspresja genu kodującego PLA2 powodowałaby nadaktywność enzymu, uruchamiając kaskadę reakcji prowadzących do uwalniania kwasów AA i DHA z pozycji Sn2 fosfolipidów błon komórkowych [68]. Znamienny wpływ na prawidłową budowę membran ma również optymalna podaż NNKT z dietą. Niedostateczne spożycie lub zły stosunek poszczególnych frakcji kwasów tłuszczowych prowadzić może do wbudowywania w błony komórkowe jednonienasyconych oraz nasyconych kwasów tłuszczowych, zaburzając funkcje membran [69].

\subsection{Dowody na słuszność koncepcji błonowej z badań post-mortem}

Doniesienia z pierwszych doświadczeń analizujących skład biochemiczny pośmiertnych struktur OUN pacjentów ze schizofrenią potwierdziły postulaty teorii błonowej. Przeprowadzona w 1991 roku analiza wyizolowanego post-mortem materiału 7 pacjentów wykazała znamienne różnice w składzie lipidów neuronów w porównaniu z grupą kontrolną [70].

Wyniki kolejnych badań dowiodły istnienia różnic w metabolizmie kwasów tłuszczowych w strukturach mózgu pacjentów ze schizofrenią w porównaniu z grupą kontrolną. Obserwowane zmiany biochemiczne były selektywne względem danych obszarów w OUN: u pacjentów ze schizofrenią obserwowano niższe stężenie kwasu DHA w korze oczodołowo-czołowej [71] oraz w korze przedczołowej [72] w porównaniu z grupą kontrolną. Zmian w poziomie kwasu DHA nie zaobserwowano w hipokampie [73], w korze śródwęchowej [74] oraz w korze czołowej [75]. Niewykluczone, że zmiany w stężeniach poszczególnych frakcji kwasów tłuszczowych są wtórne do zmian w stężeniach innych frakcji lipidów, co stwarza trudności w interpretacji wyników [72]. Wykazano między innymi znamienne niższe poziomy kwasu dokozapentaenowego $\omega-6$ (DPA) oraz kwasu AA w hipokampie osób cierpiących na schizofrenię w porównaniu z grupą kontrolną [73].

\subsection{Teoria zapalna a koncepcja błonowa schizofrenii}

Rola niedoboru bądź zaburzeń metabolizmu NNKT w rozwoju schizofrenii może wynikać także $\mathrm{z}$ immunomodulujących właściwości kwasów $\omega-3$ [76, 77]. U osób cierpiących na schizofrenię obserwowano nieprawidłową funkcję układu odpornościowego oraz obecność przeciwciał skierowanych przeciwko tkankom struktur mózgu [78]. Rozwijający się w OUN proces zapalny jest efektem działania cytokin, komórek mikrogleju, astrocytów oraz komórek odpornościowych. Mechanizmy immunologiczne umożliwiają rozpoznawanie i inaktywację cząsteczek szkodliwych dla prawidłowego funkcjonowania neuronów. Nadmierny wzrost aktywności zapalnej w OUN 
powodować może zaburzenia w zakresie neurotransmisji dopaminergicznej, serotoninergicznej, noradrenergicznej oraz glutaminergicznej [79].

Wśród czynników prowadzących do dysfunkcji mechanizmów obronnych wymienia się ekspozycję i zakażenie matki organizmami uruchamiającymi odpowiedź immunologiczną (toksoplazmoza, wirus cytomegalii, chlamydia), dysfunkcję nabłonka jelit i towarzyszącą jej dysbiozę jelitową $[80,81]$.

Zaburzeniu homeostazy układu odpornościowego sprzyja niedostateczne spożycie składników immunomodulujących [82]. Chroniczny niedobór NNKT $\omega$-3 aktywuje mechanizmy prowadzące do syntezy cytokin (IL-6 oraz TNF alfa) i białka CRP - związków o charakterze prozapalnym [83]. Wyższe spożycie kwasów tłuszczowych $\omega$-3 wiązało się z wyższym poziomem przeciwzapalnych IL-10, rozpuszczalnego receptora dla IL-6 oraz TGF- $\beta$ we krwi [84]. NNKT $\omega-3$ mogą także wywierać ochronne działanie na zmiany behawioralne oraz zmiany biochemiczne w OUN potomstwa matek o nadmiernej reakcji odpornościowej [85].

\subsection{Programowanie płodowe a deficyt NNKT $\omega-3$}

W przeprowadzonym w 1989 roku badaniu David Barker zaobserwował, że niższa masa urodzeniowa wiązała się ze zwiększonym ryzykiem choroby niedokrwiennej serca w przyszłości [86]. Spostrzeżenia brytyjskiego epidemiologa stały się punktem wyjścia do sformułowania hipotezy programowania płodowego. Ekspozycja na niekorzystne czynniki środowiskowe $\mathrm{w}$ okresie prenatalnym programuje trwałe zmiany metaboliczne organizmu. Adaptacja do warunków wewnątrzmacicznych może zwiększać ryzyko występowania wielu schorzeń w okresie dorosłości [86]. Hipotezę tę potwierdzają obserwacje retrospektywne z udziałem osób urodzonych w okresie klęsk głodowych w Holandii (lata 1944 - 1945). Niedostateczne spożycie produktów żywnościowych przez kobiety rodzące dzieci w tym okresie zwiększało ryzyko późniejszych zaburzeń gospodarki lipidowej i węglowodanowej, choroby wieńcowej serca oraz schizofrenii $[87,88,89]$.

Wpływ kwasów tłuszczowych $\omega-3$ na programowanie płodowe i późniejsze ryzyko schizofrenii pozostaje wciąż niejasny i wymaga dalszych badań. Wstępne ustalenia wykazały, że niższy poziom DHA i AA tkanek płodu oraz dieta deficytowa w NNKT w okresie karmienia piersią wiązały się z nieprawidłowym rozwojem OUN w późniejszym okresie życia $[90,91]$. W opozycji przedstawiają się wyniki badań prowadzonych przez Harpera i wsp. [92]. Kobiety, których dzieci rozwinęły zaburzenia ze spektrum schizofrenii, miały znamiennie wyższe stężenie DHA we krwi w porównaniu do matek, które urodziły zdrowe potomstwo. Próbą wytłumaczenia jest spostrzeżenie, iż wysokie spożycie owoców morza zwiększa ekspozycję na neurotoksyczne związki (rtęć, polichlorowane bifenyle
PCB) [93]. Obserwowany wzrost poziomu DHA w surowicy mógł być spowodowany zaburzeniami transportu i przenikania kwasów tłuszczowych do łożyska [92].

\section{Możliwości pomiaru przemian i spożycia NNKT}

\subsection{Test niacynowy}

Prostym w zastosowaniu badaniem pozwalającym na ocenę prawidłowości struktur błon komórkowych jest test niacynowy $[94,95,96]$. Niacyna to rozpuszczalna w wodzie witamina z grupy B, a jednorazowa doustna aplikacja wysokiej dawki nie wiąże się z zagrożeniem dla zdrowia [97]. U osób o prawidłowej odpowiedzi na doustne podanie niacyny, w wyniku rozszerzania naczyń krwionośnych, na twarzy obserwowano rumień $\mathrm{z}$ towarzyszącą podwyższoną temperatura ciała [98]. Obecnie w ocenie reakcji organizmu zastosowanie znajduje forma skórna testu niacynowego polegający na miejscowej aplikacji 1 kropli roztworu estru metylowego kwasu nikotynowego (AMN) z późniejszą oceną nasilenia reakcji skórnej [94]. Metoda jest szybka, nieinwazyjna oraz tania w eksploatacji. Mechanizm działania niacyny polega na jej zdolności do wiązania receptorów skórnych makrofagów oraz komórek Langerhansa w naskórku. W kaskadzie reakcji dochodzi do aktywacji PLA2 i uwalnianiu z membran komórkowych kwasu AA. Aktywacja cyklooksygenazy typu 2 (COX-2) prowadzi do syntezy rozszerzających naczynia krwionośne prostaglandyn D2 [95].

U pacjentów ze schizofrenią obserwowano brak lub osłabioną reakcję, zarówno w doustnym, jak i skórnym teście niacynowym [97, 98, 99]. Zmniejszona wrażliwość na działanie niacyny była niezależna od stosowanej farmakoterapii $[96,100]$ spożycia kawy oraz alkoholu [100]. Stosowanie marihuany związane było z nieprawidłową reakcją wyłącznie w grupie osób zdrowych [101]. Wyniki niektórych badań sugerują ujemną korelację między nasileniem reakcji na niacynę i wiekiem oraz płcią męską [103, 104]. Upośledzoną odpowiedź obserwowano także u krewnych osób cierpiących na schizofrenię [101]. Znamiennie mniejszą wrażliwością charakteryzowały się osoby zdrowe o wyższym obciążeniu genetycznym, w porównaniu z osobami, w których rodzinie chorował wyłącznie jeden członek [105].

\subsection{Ocena spożycia}

Ocena spożycia pozwala na oszacowanie ilości dostarczanych składników energetycznych i odżywczych diety, zarówno na poziomie indywidualnym jak i grupowym [106]. Do określenia spożywanych z dietą NNKT $\omega-3$ wykorzystywać można zwalidowane uprzednio kwestionariusze (Historia Żywienia [107], FFQ - Kwestionariusz Częstotliwości Spożycia [108]) oraz metody opierające się na określeniu spożywanych w ciągu danego dnia produktów (metoda 24 godzinnego wywiadu, metoda bieżącego notowania [109]). Każdy ze sposobów oceny spożycia 
obarczony jest ryzykiem niedoszacowania lub przeszacowania ilości dostarczanych z dietą związków [110]. Do obliczania zawartości poszczególnych składników wykorzystuje się tabele wartości odżywczej lub specjalne komputerowe programy żywieniowe $\mathrm{z}$ wbudowaną bazą produktów [111].

Badania wartości odżywczej diet mogą dostarczyć cennych informacji o wpływie żywienia na przebieg i nasilenie objawów chorobowych, czy korelacji między składnikami dostarczanymi z dietą, a późniejszym ryzykiem wystąpienia danego schorzenia. Wykazano ujemną zależność między spożyciem ryb a wystąpieniem zaburzeń psychicznych w przyszłości. Kobiety, które jadły ryby 3-4 razy w tygodniu miały o 53\% (95\% CI: 0.30-0.69) niższe ryzyko rozwoju zaburzeń psychotycznych w porównaniu z kobietami niespożywającymi ryb. Umiarkowane ilości NNKT $\omega-3(0.21 \mathrm{~g} / \mathrm{d}) \mathrm{w}$ diecie powodowały $24 \%$ spadek ryzyka wystąpienia psychozy w porównaniu z niskim spożyciem $(0.14 \mathrm{~g} / \mathrm{d})$ [112]

Dane dotyczące spożycia NNKT $\omega$-3 pacjentów ze schizofrenią są niejednoznaczne. Nieliczne badania sugerują, że pacjenci cierpiący na schizofrenię spożywają mniejsze ilości kwasów $\omega-3 \mathrm{w}$ porównaniu z osobami zdrowymi [113]. Wyniki innych obserwacji wykazały, iż ilość spożywanych NNKT jest wyższa u osób chorych, jednakże wynika z większej, w porównaniu z osobami zdrowymi, ilości kwasów $\omega-6$ w diecie. Spożycie NNKT $\omega-3$ nie różniło się między grupami pacjentów i kontrolną [114]. Przeprowadzone w Polsce badanie wykazało, iż pacjenci ze schizofrenią spożywają nieadekwatne do zalecanych ilości NNKT, a dzienne pobranie pokrywało około $28 \%$ zapotrzebowania [115]. Zaburzenia funkcji poznawczych oraz wynikający ze stanu zdrowia brak motywacji mogą być predykatorem decyzji żywieniowych i deficytowej w składniki odżywcze diety [113]. U pacjentów cierpiących na schizofrenię wykazano także ujemną korelację między spożyciem NNKT a nasileniem objawów choroby, niezależnie od stosowanej farmakoterapii [116].

\subsection{Stan odżywienia}

Celem oceny stanu odżywienia jest oszacowanie zagrożenia wystąpienia niedoboru substancji pokarmowych. Na stan odżywienia danym składnikiem wpływają jego zwyczajowe spożycie, metabolizm i wykorzystania w organizmie oraz zjawiska patologiczne prowadzące do zaburzenia tych procesów [117]. Testem badającym zaopatrzenie organizmu w kwasy tłuszczowe EPA i DHA może być analiza biochemiczna krwi [118]. Poziom NNKT w surowicy krwi nie pozwala na oszacowanie długoterminowego pobrania z dietą, a ilość odzwierciedla aktualne spożycie. Wskaźnikiem który lepiej koreluje z długoterminowym spożyciem NNKT jest wysycenie poszczególnymi frakcjami tłuszczów błon komórkowych erytrocy- tów. Słabszą zależność w porównaniu do czerwonych krwinek obserwowano także w stosunku do osocza [119].

Metaanaliza 14 badań wykazała zależny od stosowanej farmakoterapii stan odżywienia NNKT $\omega$-3 pacjentów cierpiących na schizofrenię [120]. Chorzy, którzy nie stosowali farmakoterapii (medication-naive patients) oraz osoby leczone środkami typowymi miały, w porównaniu do osób zdrowych, znamiennie niższe stężenie kwasów arachidonowego (AA), dokazaheksaenowego (DHA) oraz kwasu dokozapentaenowego (DPA). U pacjentów przyjmujący środki typowe obserwowano także niższe niż w grupie kontrolnej poziomy kwasów linolowego (LA), dihomo- $\gamma$-linolowego (DGLA), eikozapentaenowego (EPA) oraz dokozatetraenowego (DTA). U pacjentów leczonych atypowo obserwowano spadek stężenia kwasu dokozaheksaenowego (DHA) [120]. Opublikowana rok później metaanaliza potwierdziła tezę o zmienionym składzie biochemicznym błon erytrocytów pacjentów schizofrenicznych [120]. Zarówno u osób niestosujących farmakoterapii jak i leczonych przeciwpsychotycznie wykazano obniżone stężenia kwasów dokozapentaenowego (DPA), dokozaheksaenowego (DHA) i arachidonowego (AA). Stężenie kwasu linolowego (LA) było niższe jedynie w grupie pacjentów przyjmujących leki.

Sugeruje się, że niewłaściwy sposób żywienia nie jest jedynym predykatorem nieprawidłowego stanu odżywienia kwasami $\omega-3$ pacjentów [121]. Na zawartość NNKT $\omega-3 \mathrm{w}$ strukturach organizmu wpływają między innymi płeć, używki [122], przebieg leczenia [123].

Dotychczasowe obserwacje skupiały się na pacjentach $\mathrm{w}$ ostrej fazie choroby, pochodzących z państw wysokorozwiniętych [120, 121]. Badanie przeprowadzone $w$ grupie młodych, niedawno zdiagnozowanych pacjentów dostarcza wyników sprzecznych z dotychczas osiągniętymi. [124]. Osoby chore oraz ich rodzeństwo miały wyższy w porównaniu z grupą kontrolną poziom NNKT - kwasu dokozaheksaenowego (DHA), dokozapentaenowego (DPA), arachidonowego (AA), kwasu nerwonowego (NA). Poziom kwasu linolowego (LA) był znamiennie wyższy jedynie w grupie rodzeństwa osób dotkniętych chorobą. Różnice w wynikach badań wynikać mogą ze struktury spożycia kwasów tłuszczowych. Obserwowano wyższe poziomy NNKT $\omega-3$ w grupie pacjentów o niższym wskaźniku BMI, a dane o nawykach żywieniowych i strukturze spożycia pacjentów były ograniczone [124].

\section{Podsumowanie}

Dowody z badań epidemiologicznych oraz tych przeprowadzonych na modelu zwierzęcym potwierdzają prawdopodobny wpływ niedostatecznego spożycia oraz zaburzeń metabolizmu NNKT w rozwoju i przebiegu schizofrenii. Różnice w przedstawianych wynikach badań oraz sprzeczne rezultaty obserwacji wynikać mogą ze 
zmiennych środowiskowych oraz różnic genetycznych wśród grup objętych obserwacją. Wysoka heterogeniczność metodologiczna stawia konieczność prowadzania dalszych, dobrze zaprojektowanych badań w tym zakresie [121]. Wyjaśnienie dokładnej roli NNKT $\mathrm{w}$ patofizjologii schizofrenii umożliwi ustalenie rekomendacji dotyczących optymalnego spożycia NNKT kwasów tłuszczowych $\omega-3$ pacjentów przyczyniając się do poprawy stanu zdrowia i redukcji objawów choroby.

\section{References:}

1. Shen W.W. Pharmacotherapy of schizophrenia: the American current status. Keio J Med. 1994; 43(4): 192-200.

2. Geddes J., Freemantle N., Harrison P., Bebbington P. Atypical antipsychotics in the treatment of schizophrenia: systematic overview and meta-regression analysis. BMJ, 2000; 321(7273): 1371-6.

3. Bou Khalil R. Atypical antipsychotic drugs, schizophrenia, and metabolic syndrome in non-Euro-American societies. Clin Neuropharmacol. 2012; 35(3): 141-7.

4. Ventriglio A., Gentile A., Stella E., Bellomo A. Metabolic issues in patients affected by schizophrenia: clinical characteristics and medical management. Front Neurosci. 2015; 9:297.

5. Almandil N.B., Liu Y., Murray M.L., Besag F.M., Aitchison K.J., Wong I.C. Weight gain and other metabolic adverse effects associated with atypical antipsychotic treatment of children and adolescents: a systematic review and meta-analysis. Paediatr Drugs. 2013; 15(2): 139-50.

6. Masa-Font R., Fernández-San-Martín M.I., Martín López L.M., Alba Muñoz A.M., Oller Canet S., Martín Royo J., San Emeterio Echevarría L., Olona Tabueña N., Ibarra Jato M., Barroso García A., González Tejón S., Tajada Vitales C., Díaz Mújica B., Viñas Cabrera L., Sanchís Catalán R., Salvador Barbarroja T. The effectiveness of a program of physical activity and diet to modify cardiovascular risk factors in patients with severe mental illness after 3-month follow-up: CAPiCOR randomized clinical trial. Eur Psychiatry. 2015; 30(8): 1028-36.

7. Kraeuter A.K., Loxton H., Lima B.C., Rudd D., Sarnyai Z. Ketogenic diet reverses behavioral abnormalities in an acute NMDA receptor hypofunction model of schizophrenia. Schizophr Res. 2015; 169(1-3): 491-3.

8. Sepehrmanesh Z., Kolahdooz F., Abedi F., Mazroii N., Assarian A., Asemi Z., Esmaillzadeh A. Vitamin D Supplementation Affects the Beck Depression Inventory, Insulin Resistance, and Biomarkers of Oxidative Stress in Patients with Major Depressive Disorder: A Randomized, Controlled Clinical Trial. J Nutr. 2016; 146(2): 243-8.

9. Jacka F.N., Ystrom E., Brantsaeter A.L., Karevold E., Roth C., Haugen M., Meltzer H.M., Schjolberg S., Berk M. Maternal and early postnatal nutrition and mental health of offspring by age 5 years: a prospective cohort study. J Am Acad Child Adolesc Psychiatry. 2013; 52(10): 1038-47.

10. Jacka F.N., Cherbuin N., Anstey K.J., Butterworth P. Dietary patterns and depressive symptoms over time: examining the relationships with socioeconomic position, health behaviours and cardiovascular risk. PLoS One. 2014; 9(1): e87657.

11. Jacka F.N, Cherbuin N., Anstey K.J., Sachdev P., Butterworth P. Western diet is associated with a smaller hippocampus: a longitudinal investigation. BMC Med. 2015; 13: 215.

12. Logan A.C., Jacka FN. Nutritional psychiatry research: an emerging discipline and its intersection with global urbanization, environmental challenges and the evolutionary mismatch. J Physiol Anthropol. 2014; 24: 33:22.
13. Mossaheb N., Schloegelhofer M., Schaefer M.R., Fusar-Poli P., Smesny S., McGorry P., Berger G., Amminger GP. Polyunsaturated fatty acids in emerging psychosis. Curr Pharm Des. 2012; 18(4): 576-91.

14. Appleton K.M., Sallis H.M., Perry R., Ness A.R., Churchill R. $\omega-3$ Fatty acids for major depressive disorder in adults: an abridged Cochrane review. BMJ Open. 2016; 6(3): e010172.

15. Ratnayake W.M., Galli C. Fat and fatty acid terminology, methods of analysis and fat digestion and metabolism: a background review paper. Ann Nutr Metab. 2009; 55(1-3): 8-43.

16. Swanson D., Block R., Mousa S.A. Omega-3 fatty acids EPA and DHA: health benefits throughout life. Adv Nutr. 2012; 3(1): 1-7.

17. Baker E.J., Miles E.A., Burdge G.C., Yaqoob P., Calder P.C. Metabolism and Functional Effects of Plant-Derived Omega-3 Fatty Acids in Humans. Prog Lipid Res. 2016 Aug 2. pii: S01637827(16)30030-3.

18. Nakamura M.T., Nara T.Y. Essential fatty acid synthesis and its regulation in mammals. Prostaglandins Leukot Essent Fatty Acids. 2003; 68(2): 145-50.

19. Zhang J.Y., Kothapalli K.S., Brenna J.T. Desaturase and elongaselimiting endogenous long-chain polyunsaturated fatty acid biosynthesis. Curr Opin Clin Nutr Metab Care. 2016; 19(2): 103-10.

20. Yao M., Hou L., Xie T., Liu Y., Dai D., Shi Y., Lian K., Jiang L. The biosynthesis of DHA is increased in the liver of diabetic rats induced by high-fat diets and STZ, in correlation with increased activity of peroxisomal $\beta$-oxidation. Eur. J. Lipid Sci. Technol. 2016; 118: 137-146..

21. Rapoport S.I., Rao J.S., Igarashi M. Brain metabolism of nutritionally essential polyunsaturated fatty acids depends on both the diet and the liver. Prostaglandins Leukot Essent Fatty Acids. 2007; 77(5-6): 251-61.

22. Hussein N., Ah-Sing E., Wilkinson P., Leach C., Griffin B.A., Millward D.J. Long-chain conversion of [13C]linoleic acid and alphalinolenic acid in response to marked changes in their dietary intake in men. J Lipid Res. 2005; 46(2): 269-80.

23. Pawlosky R., Hibbeln J., Lin Y., Salem N.Jr. n-3 fatty acid metabolism in women. Br J Nutr. 2003; 90(5): 993-4.

24. Liou Y.A., Król D.J., Zibrik D., Innis S.M. Decreasing linoleic acid with constant alpha-linolenic acid in dietary fats increases (n-3) eicosapentaenoic acid in plasma phospholipids in healthy men. J Nutr 2007; 137(4): 945-52.

25. Kang Z.B., Ge Y., Chen Z., Cluette-Brown J., Laposata M., Leaf A., Kang J.X. Adenoviral gene transfer of Caenorhabditis elegans $n--3$ fatty acid desaturase optimizes fatty acid composition in mammalian cells. Proc Natl Acad Sci U S A. 2001; 98(7): 4050-4.

26. Simopoulos A.P. Evolutionary Aspects of Diet: The Omega-6/Omega-3 Ratio and the Brain. Mol Neurobiol. 2011; 44(2): 203-15.

27. Michael-Titus T.A. Omega-3 Fatty Acids: Their Neuroprotective and Regenerative Potential in Traumatic Neurological Injury. Clin Lipidology. 2009; 4(3): 343-353.

28. Hadzhieva B., Dimitrov M., Obreshkova D., Petkova V., Atanasov P., Kasnakova P. Omega-3 polyunsaturated fatty acids metabolism and prevention of some socially significant diseases. WJPPS. 2016; 5(7): 304-315.

29. Kołodziejczyk M. Consumption of fish and fishery products in Poland--analysis of benefits and risks. Rocz Panstw Zakl Hig. 2007; 58(1): 287-93.

30. Kunachowicz H., Nadolna I., Przygoda B., Iwanow K. Tabele wartości odżywczej produktów spożywczych i potraw. Wydanie III rozszerzone i uaktualnione. InstytutŻywności i Żywienia, Warszawa 2005.

31. WHO Expert consultation. Fats and Fatty Acids in Human Nutrition. Interim Summary of Conclusion and Dietary Recommendations on Total Fat and Fatty Acids. November 10-14, 2008 WHO HQ Geneva.

32. EFSA Panel on Dietetic Products, Nutrition, and Allergies (NDA). Scientific Opinion on Dietary Reference Values for fats, including saturated fatty acids, polyunsaturated fatty acids, monounsaturated fatty acids, trans fatty acids, and cholesterol. EFSA Journal. 2010; 8(3): 1461. 
33. Szponar L., Mojska H., Ołtarzewski M. Tłuszcze. W: Jarosz M. red., Normy żywienia dla populacji polskiej - nowelizacja, Warszawa; Instytut Żywności i Żywienia, 2012, s. 48.

34. Freeman M.P., Hibbeln J.R., Wisner K.L., Davis J.M., Mischoulon D., Peet M., Keck P.E. Jr., Marangell L.B., Richardson A.J., Lake J., Stoll A.L. Omega-3 fatty acids: evidence basis for treatment and future research in psychiatry. J Clin Psychiatry. 2006; 67(12): 1954-67.

35. Demar J.C.Jr., Ma K., Chang L., Bell J.M., Rapoport S.I. alpha-Linolenic acid does not contribute appreciably to docosahexaenoic acid within brain phospholipids of adult rats fed a diet enriched in docosahexaenoic acid. J Neurochem. 2005; 94(4): 1063/76.

36. Ouellet M., Emond V., Chen C.T., Julien C., Bourasset F., Oddo S., LaFerla F., Bazinet R.P., Calon F. Diffusion of docosahexaenoic and eicosapentaenoic acids through the blood-brain barrier: An in situ cerebral perfusion study. Neurochem Int. 2009; 55(7): 476-82.

37. Rapoport S.I., Ramadan E., Basselin M. Docosahexaenoic acid (DHA) incorporation into the brain from plasma, as an in vivo biomarker of brain DHA metabolism and neurotransmission. Prostaglandins Other Lipid Mediat. 2011; 96(1-4): 109-13.

38. Bosch-Bouju C., Sophie Layé S. Dietary Omega-6/Omega-3 and Endocannabinoids: Implications for Brain Health and Diseases. Cannabinoids in Health and Disease, Prof. Rosaria Meccariello (Ed.), InTech, DOI: 10.5772/62498. Available from: http://www.intechopen.com/books/cannabinoids-in-healthand-disease/dietary-omega-6-omega-3-and-endocannabinoidsimplications-for-brain-health-and-diseases.

39. Chen C.T., Domenichiello A.F., Trépanier M.O,, Liu Z., Masoodi M., Bazinet R.P. The low levels of eicosapentaenoic acid in rat brain phospholipids are maintained via multiple redundant mechanisms. J Lipid Res. 2013; 54(9): 2410-22.

40. Strokin M., Sergeeva M., Reiser G. Docosahexaenoic acid and arachidonic acid release in rat brain astrocytes is mediated by two separate isoforms of phospholipase $\mathrm{A} 2$ and is differently regulated by cyclic AMP and Ca2+. Br J Pharmacol. 2003; 139(5): 1014-22.

41. Gururajan A., Malone D.T. Does cannabidiol have a role in the treatment of schizophrenia? Schizophr Res. 2016. pii: S09209964(16)30289-4.

42. Zeman M., Jirak R., Vecka M., Raboch J., Zak A. N-3 polyunsaturated fatty acids in psychiatric diseases: mechanisms and clinical data. Neuro Endocrinol Lett. 2012; 33(8): 736-48.

43. Wainwright P.E. Dietary essential fatty acids and brain function: a developmental perspective on mechanisms. Proc Nutr Soc. 2002; 61(1): 61-9.

44. Simopoulos A.P. The importance of the omega-6/omega-3 fatty acid ratio in cardiovascular disease and other chronic diseases. Exp Biol Med (Maywood). 2008; 233(6): 674-88.

45. Kitson A.P., Smith T.L., Marks K.A., Stark K.D. Tissue-specific sex differences in docosahexaenoic acid and Delta6-desaturase in rats fed a standard chow diet. Appl Physiol Nutr Metab, 2012; 37(6): 1200-11.

46. Chen C.T., Bazinet R.P. $\beta$-oxidation and rapid metabolism, but not uptake regulate brain eicosapentaenoic acid levels. Prostaglandins Leukot Essent Fatty Acids. 2015; 92: 33-40.

47. Kitajka K., Puskás L.G., Zvara A., Hackler L.Jr., Barceló-Coblijn G., Yeo Y.K., Farkas T. The role of n-3 polyunsaturated fatty acids in brain: modulation of rat brain gene expression by dietary $n-3$ fatty acids. Proc Natl Acad Sci U S A. 2002; 99(5):2 619-24.

48. McNamara R.K., Ostrander M., Abplanalp W., Richtand N.M., Benoit S.C., Clegg D.J. Modulation of phosphoinositide-protein kinase $\mathrm{C}$ signal transduction by omega-3 fatty acids: implications for the pathophysiology and treatment of recurrent neuropsychiatric illness. Prostaglandins Leukot Essent Fatty Acids. 2006 Oct; 75(4-5): 237-57.

49. Church M.W., Jen K.L., Dowhan L.M., Adams B.R., Hotra J.W. Excess and deficient omega-3 fatty acid during pregnancy and lactation cause impaired neural transmission in rat pups. Neurotoxicol Teratol. 2008; 30(2):107-17.
50. Louchami K., Zhang Y., Carpentier Y.A., Chardigny J.M., Malaisse W.J., Herchuelz A., Sener A. Carbamylcholine and ouabain effects on $\mathrm{Ca} 2+$ handling and insulin release in islets from rats depleted in long-chain polyunsaturated omega 3 fatty acids. Endocrine. 2007; 32(2): 148-54.

51. Nirwane A., Pawar V., Majumdar A. Therapeutic interventions using a combination of Telmisartan and omega 3-fatty acids in sodium arsenite-induced vascular endothelial dysfunction in rats: modulation through ATP-sensitive K+ channels and eNOS. J Complement Integr Med. 2015; 12(2): 143-51.

52. Calderon F., Kim H.Y. Docosahexaenoic acid promotes neurite growth in hippocampal neurons. J Neurochem. 2004; 90(4): 979-88.

53. Cao D., Kevala K., Kim J., Moon HS., Jun S.B., Lovinger D., Kim H.Y. Docosahexaenoic acid promotes hippocampal neuronal development and synaptic function. J Neurochem. 2009; 111(2): 510-21.

54. Brenes O., Giachello C.N., Corradi A.M., Ghirardi M., Montarolo P.G. Synapsin knockdown is associated with decreased neurite outgrowth, functional synaptogenesis impairment, and fast highfrequency neurotransmitter release. J Neurosci Res. 2015; 93(10): 1492-506.

55. He C., Qu X., Cui L., Wang J., Kang J.X. Improved spatial learning performance of fat-1 mice is associated with enhanced neurogenesis and neuritogenesis by docosahexaenoic acid. Proc Natl Acad Sci U S A. 2009; 106(27): 11370-5.

56. Dyall S.C., Michael G.J., Michael-Titus A.T. Omega-3 fatty acids reverse age-related decreases in nuclear receptors and increase neurogenesis in old rats. J Neurosci Res. 2010; 88(10): 2091-102.

57. Abdel-Maksoud S.M., Hassanein S.I., Gohar N.A., Attia S.M., Gad M.Z. Investigation of brain-derived neurotrophic factor (BDNF) gene expression in hypothalamus of obese rats: Modulation by omega-3 fatty acids. Nutr Neurosci. 2016; 1:1-6.

58. Kim H.Y., Spector A.A, Xiong Z.M. A synaptogenic amide Ndocosahexaenoylethanolamide promotes hippocampal development. Prostaglandins Other Lipid Mediat. 2011; 96(1-4): 114-20.

59. Yao C., Zhang J., Chen F., Lin Y. Neuroprotectin D1 attenuates brain damage induced by transient middle cerebral artery occlusion in rats through TRPC6/CREB pathways. Mol Med Rep. 2013; 8(2): 543-50.

60. Cortina M.S., He J., Russ T., Bazan N.G., Bazan H.E. Neuroprotectin D1 restores corneal nerve integrity and function after damage from experimental surgery. Invest Ophthalmol Vis Sci. 2013; 54(6): 4109-16.

61. Chalon S. Omega-3 fatty acids and monoamine neurotransmission. Prostaglandins Leukot Essent Fatty Acids. 2006; 75(4-5): 259-69.

62. Zimmer L., Delion-Vancassel S., Durand G., Guilloteau D., Bodard S., Besnard J.C., Chalon S. Modification of dopamine neurotransmission in the nucleus accumbens of rats deficient in $n-3$ polyunsaturated fatty acids. J Lipid Res. 2000; 41(1): 32-40.

63. Zimmer L., Vancassel S., Cantagrel S., Breton P., Delamanche S., Guilloteau D., Durand G., Chalon S. The dopamine mesocorticolimbic pathway is affected by deficiency in n-3 polyunsaturated fatty acids. Am J Clin Nutr. 2002; 75(4): 662-7.

64. Aïd S., Vancassel S., Poumès-Ballihaut C., Chalon S., Guesnet P., Lavialle M. Effect of a diet-induced n-3 PUFA depletion on cholinergic parameters in the rat hippocampus. J Lipid Res. 2003; 44(8): 1545-51.

65. Kodas E., Galineau L., Bodard S., Vancassel S., Guilloteau D., Besnard J.C., Chalon S. Serotoninergic neurotransmission is affected by $n-3$ polyunsaturated fatty acids in the rat. J Neurochem. 2004; 89(3): 695-702.

66. Horrobin D.F. Schizophrenia as a prostaglandin deficiency disease. Lancet. 1977; 1(8018): 936-7.

67. Horrobin, D.F., Glen, A.I, Hudson, C.J. Possible relevance of phospholipid abnormalities and genetic interactions in psychiatric disorders: the relationship between dyslexia and schizophrenia. Med. Hypotheses. 1995; 45(6): 605-613. 
68. Horrobin D.F. Schizophrenia as a membrane lipid disorder which is expressed throughout the body. Prostaglandins Leukot Essent Fatty Acids. 1996; 55(1-2): 3-7.

69. Horrobin D.F. The membrane phospholipid hypothesis as a biochemical basis for the neurodevelopmental concept of schizophrenia. Schizophr Res. 1998; 30(3): 193-208.

70. Horrobin D.F., Manku M.S., Hillman H., Iain A., Glen M. Fatty acid levels in the brains of schizophrenics and normal controls. Biol Psychiatry. 1991; 30(8): 795-805.

71. McNamara R.K., Jandacek R., Rider T., Tso P., Hahn C.G., Richtand N.M., Stanford K.E. Abnormalities in the fatty acid composition of the postmortem orbitofrontal cortex of schizophrenic patients: gender differences and partial normalization with antipsychotic medications. Schizophr Res. 2007; 91(1-3): 37-50.

72. Taha A.Y, Cheon Y., Ma K., Rapoport S.I., Rao J.S. Altered fatty acid concentrations in prefrontal cortex of schizophrenic patients. J Psychiatr Res. 2013; 47(5): 636-43.

73. Hamazaki K., Choi K.H., Kim H.Y. Phospholipid profile in the postmortem hippocampus of patients with schizophrenia and bipolar disorder: no changes in docosahexaenoic acid species. J Psychiatr Res. 2010; 44(11): 688-93.

74. Hamazaki K., Hamazaki T., Inadera H. Abnormalities in the fatty acid composition of the postmortem entorhinal cortex of patients with schizophrenia, bipolar disorder, and major depressive disorder. Psychiatry Res. 2013; 210(1): 346-50.

75. Hamazaki K., Maekawa M., Toyota T., Iwayama Y., Dean B., Hamazaki T., Yoshikawa T. Fatty acid composition and fatty acid binding protein expression in the postmortem frontal cortex of patients with schizophrenia: A case-control study. Schizophr Res. 2016; 171(1-3): 225-32.

76. Frimmel K., Vlkovicova J., Sotnikova R., Navarova J., Bernatova I., Okruhlicova L. The effect of omega-3 fatty acids on expression of connexin-40 in Wistar rat aorta after lipopolysaccharide administration. J Physiol Pharmacol. 2014; 65(1): 83-94.

77. Zendedel A., Habib P., Dang J., Lammerding L., Hoffmann S., Beyer C., Slowik A. Omega-3 polyunsaturated fatty acids ameliorate neuroinflammation and mitigate ischemic stroke damage through interactions with astrocytes and microglia. J Neuroimmunol. 2015; 278:200-11.

78. Rothermundt M., Arolt V., Bayer T.A. Review of immunological and immunopathological findings in schizophrenia. Brain Behav Immun. 2001; 15(4): 319-39.

79. Müller N., Weidinger E., Leitner B., Schwarz M.J. The role of inflammation in schizophrenia. Front Neurosci. 2015; 9:372.

80. Severance E.G, Alaedini A., Yang S., Halling M., Gressitt K.L., Stallings C.R., Origoni A.E., Vaughan C., Khushalani S., Leweke F.M., Dickerson F.B., Yolken R.H. Gastrointestinal inflammation and associated immune activation in schizophrenia. Schizophr Res. 2012; 138(1): 48-53.

81. Kelly J.R, Borre Y., O' Brien C., Patterson E., El Aidy S., Deane J., Kennedy P.J., Beers S., Scott K., Moloney G., Hoban A.E., Scott L., Fitzgerald P., Ross P., Stanton C., Clarke G., Cryan J.F., Dinan T.G. Transferring the blues: Depression-associated gut microbiota induces neurobehavioural changes in the rat. J Psychiatr Res. 2016; 82: 109-118.

82. Prescott S.L. Role of dietary immunomodulatory factors in the development of immune tolerance. Nestle Nutr Workshop Ser Pediatr Program. 2009; 64: 185-94.

83. McNamara R.K., Jandacek R., Rider T., Tso P., Cole-Strauss A., Lipton J.W. Omega-3 fatty acid deficiency increases constitutive pro-inflammatory cytokine production in rats: relationship with central serotonin turnover. Prostaglandins Leukot Essent Fatty Acids. 2010; 83(4-6): 185-91.

84. Ferrucci L., Cherubini A., Bandinelli S., Bartali B., Corsi A., Lauretani F., Martin A., Andres-Lacueva C., Senin U., Guralnik J.M. Relationship of plasma polyunsaturated fatty acids to circulating inflammatory markers. J Clin Endocrinol Metab. 2006; 91(2): 439-46.
85. Li Q., Leung Y.O., Zhou I., Ho L.C., Kong W., Basil P., Wei R., Lam S., Zhang X., Law A.C., Chua S.E., Sham P.C., Wu E.X., McAlonan G.M. Dietary supplementation with n-3 fatty acids from weaning limits brain biochemistry and behavioural changes elicited by prenatal exposure to maternal inflammation in the mouse model. Transl Psychiatry. 2015; 5:e641.

86. Barker D.J., Winter P.D., Osmond C., Margetts B., Simmonds S.J. Weight in infancy and death from ischaemic heart disease. Lancet. 1989; 2(8663): 577-80.

87. Lumey L., Stein A.D., Kahn H.S., van der Pal-de Bruin K.M., Blauw G., Zybert P.A., Susser E.S. Cohort profile: The Dutch Hunger Winter Families Study. Int J Epidemiol. 2007; 36(6): 1196-204.

88. Lumey L., Stein A.D., Kahn H.S., Romijn J. Lipid profi les in middleaged men and women after famine exposure during gestation: The Dutch Hunger Winter Families Study. Am J Clin Nutr. 2009 ;89(6): 1737-43

89. de Rooij S., Painter R., Roseboom T., Phillips D., Osmond C., Barker D., Tanck M., Michels R., Bossuyt P., Bleker O. Glucose tolerance at age 58 and the decline of glucose tolerance in comparison with age 50 in people prenatally exposed to the Dutch famine. Diabetologia. 2006; 49(4): 637-43.

90. Kodas E., Vancassel S., Lejeune B., Guilloteau D., Chalon S. Reversibility of n-3 fatty acid deficiency-induced changes in dopaminergic neurotransmission in rats: critical role of developmental stage. J Lipid Res. 2002; 43(8): 1209-19.

91. Dijck-Brouwer D.A., Hadders-Algra M., Bouwstra H., Decsi T., Boehm G., Martini I.A., Boersma E.R., Muskiet F.A. Lower fetal status of docosahexaenoic acid, arachidonic acid and essential fatty acids is associated with less favorable neonatal neurological condition. Prostaglandins Leukot Essent Fatty Acids. 2005; 72(1): 21-8.

92. Harper K.N., Hibbeln J.R., Deckelbaum R., Quesenberry C.P. Jr., Schaefer C.A., Brown A.S. Maternal serum docosahexaenoic acid and schizophrenia spectrum disorders in adult offspring. Schizophr Res. 2011; 128(1-3): 30-36.

93. Torpy J.M., Lynm C., Glass R.M. Eating fish: health benefits and risks. JAMA. 2006; 296(15): 1926.

94. Messamore E., Hoffman W.F., Janowsky A. The niacin skin flush abnormality in schizophrenia: a quantitative dose-response study. Schizophr Res. 2003; 62(3): 251-8.

95. Nadalin S., Buretić-Tomljanović A., Rubesa G., Tomljanović D., Gudelj L. Niacin skin flush test: a research tool for studying schizophrenia. Psychiatr Danub. 2010; 22(1): 14-27.

96. Górniak M., Rybakowski J. Test niacynowy w schizofrenii: przegląd piśmiennictwa i wstępne wyniki badań własnych. Farmakoterapia w Psychiatrii i Neurologii. 2012; 1: 7-16.

97. Kashyap M.L., McGovern M.E., Berra K., Guyton J.R., Kwiterovich P.O., Harper W.L., Toth P.D., Favrot L.K., Kerzner B., Nash S.D., Bays H.E, Simmons P.D. Long-term safety and efficacy of a oncedaily niacin/lovastatin formulation for patients with dyslipidemia. Am J Cardiol. 2002; 89(6): 672-8.

98. Horrobin D.F. Schizophrenia: a biochemical disorder? Biomedicine. 1980; 32(2): 54-5.

99. Yao J.K., Dougherty G.G. Jr., Gautier C.H., Haas G.L., Condray R., Kasckow J.W., Kisslinger B.L., Gurklis J.A., Messamore E. Prevalence and Specificity of the Abnormal Niacin Response: A Potential Endophenotype Marker in Schizophrenia. Schizophr Bull. 2016; 42(2): 369-76.

100. Ross B.M., Hughes B., Turenne S., Seeman M., Warsh J.J. Reduced vasodilatory response to methylnicotinate in schizophrenia as assessed by laser Doppler flowmetry. Eur Neuropsychopharmacol. 2004; 14(3): 191-7.

101.Lin S.H., Liu C.M., Chang S.S., Hwu H.G., Liu S.K., Hwang T.J., Hsieh M.H., Guo S.C., Chen W.J. Familial aggregation in skin flush response to niacin patch among schizophrenic patients and their nonpsychotic relatives. Schizophrenia Bull. 2007; 33(1): 174-82. 
102.Smesny S., Rosburg T., Baur K., Rudolph N., Sauer H. Cannabinoids influence lipid-arachidonic acid pathways in schizophrenia. Neuropsychopharmacology. 2007; 32(10): 2067-73.

103.Smesny S., Riemann S., Riehemann S., Bellemann M.E., Sauer H. Quantitative measurement of induced skin reddening using optical reflection spectroscopy- -methodology and clinical application. Biomed Tech (Berl) 2001; 46(10): 280-6.

104.Smesny S., Rosburg T., Klemm S., Riemann S., Baur K., Rudolph N., Grunwald S., Sauer H. The influence of age and gender on niacin skin test results - implications for the use as a biochemical marker in schizophrenia. J Psychiatr Res. 2004; 38(5): 537-43.

105. Chang S.S., Liu C.M., Lin S.H., Hwu H.G., Hwang T.J., Liu S.K., Hsieh M.H., Guo S.C., Chen W.J. Impaired flush response to niacin skin patch among schizophrenia patients and their nonpsychotic relatives: The effect of genetic loading. Schizophr Bull. 2009; 35(1): 213-21.

106.Gronowska-Senger A., Metody oceny stanu odżywienia, W: Gronowska-Senger A. red., Zarys oceny żywienia, Warszawa; Wyd. SGGW: 2013, s. 57-77.

107.Shiraishi M., Haruna M., Matsuzaki M., Murayama R., Sasaki S. The biomarker-based validity of a brief-type diet history questionnaire for estimating eicosapentaenoic acid and docosahexaenoic acid intakes in pregnant Japanese women. Asia Pac J Clin Nutr. 2015; 24(2): 316-22.

108.Praagman J., Adolphs A.P., van Rossum C.T., Sluijs I., van der Schouw Y.T., Beulens J.W. Reproducibility and relative validity of a FFQ to estimate the intake of fatty acids. Br J Nutr. 2016; 115(12): 2154-61.

109.Frankenfeld C.L., Poudrier J.K., Waters N.M., Gillevet P.M., Xu Y. Dietary intake measured from a self-administered, online 24hour recall system compared with 4-day diet records in an adult US population. J Acad Nutr Diet. 2012; 112(10): 1642-7.

110.Thompson E.F, Subar F.A. Dietary Assessment Methodology. W: Coulston M.A., Boushey J.C., Ferruzzi M. Nutrition in the Prevention and Treatment of Disease (Third Edition)., Oxford; Elsevier: 2013. s. 5-30.

111.Pereira-da-Silva L., Cabo C., Moreira A.C., Virella D., Guerra T., Camoes T., Silva A.R., Neves R., Ferreira G.C. The adjusted effect of maternal body mass index, energy and macronutrient intakes during pregnancy, and gestational weight gain on body composition of full-term neonates. Am J Perinatol. 2014; 31(10): 875-82.

112.Hedelin M., Löf M., Olsson M., Lewander T., Nilsson B., Hultman C.M., Weiderpass E. Dietary intake of fish, omega-3, omega- 6 polyunsaturated fatty acids and vitamin $D$ and the prevalence of psychotic-like symptoms in a cohort of 33,000 women from the general population. BMC Psychiatry. 2010;10: 38.

113.Henderson D.C., Borba C.P., T.B., Boxill R., Nguyen D.D., Culhane M.A., Louie P., Cather C., Eden Evins A., Freudenreich O., Taber S.M., Goff D.C. Dietary intake profile of patients with schizophrenia. Ann Clin Psychiatry. 2006; 18(2): 99-105.

114.Strassnig M., Singh Brar J., Ganguli R. Dietary fatty acid and antioxidant intake in community-dwelling patients suffering from schizophrenia. Schizophr Res. 2005; 76(2-3): 343-51.

115.Konarzewska B., Stefańska E., Wendołowicz A., Cwalina U., Golonko A., Małus A., Kowzan U., Szulc A., Rudzki L., Ostrowska L. Visceral obesity in normal-weight patients suffering from chronic schizophrenia. BMC Psychiatry. 2014; 14: 35.

116.Stokes C., Peet M. Dietary sugar and polyunsaturated fatty acid consumption as predictors of severity of schizophrenia symptoms. Nutr Neurosci. 2004; 7(4): 247-249.

117.Gronowska-Senger A., Charakterystyka i zasady wyboru metod, W: Gronowska-Senger A. red., Przewodnik metodyczny badań sposobu żywienia., Warszawa; Wyd. Komitetu Nauki o Żywieniu Człowieka Polskiej Akademii Nauk: 2013, s. 5-16.
118.Hodson L., Skeaff C.M., Fielding B.A. Fatty acid composition of adipose tissue and blood in humans and its use as a biomarker of dietary intake. Prog Lipid Res. 2008; 47(5): 348-80.

119.Sun Q., Ma J., Campos H., Hankinson S.E., Hu F.B. Comparison between plasma and erythrocyte fatty acid content as biomarkers of fatty acid intake in US women. Am J Clin Nutr. 2007; 86(1): 74-81.

120.van der Kemp W.J., Klomp D.W., Kahn R.S., Luijten P.R., Hulshoff Pol H.E. A meta-analysis of the polyunsaturated fatty acid composition of erythrocyte membranes in schizophrenia. Schizophr Res. 2012; 141(2-3): 153-61.

121.Hoen W.P., Lijmer J.G., Duran M., Wanders R.J., van Beveren N.J., de Haan L. Red blood cell polyunsaturated fatty acids measured in red blood cells and schizophrenia: a meta-analysis. Psychiatry Res. 2013; 207(1-2): 1-12.

122.Hibbeln J.R., Makino K.K., Martin C.E., Dickerson F., Boronow J., Fenton W.S. Smoking, gender, and dietary influences on erythrocyte essential fatty acid composition among patients with schizophrenia or schizoaffective disorder.Smoking, gender, and dietary influences on erythrocyte essential fatty acid composition among patients with schizophrenia or schizoaffective disorder. Biol Psychiatry. 2003; 53(5): 431-41.

123.Sumiyoshi T., Higuchi Y., Matsui M., Itoh H., Uehara T., Itoh T., Arai H., Takamiya C., Suzuki M., Kurachi M. Membrane fatty acid levels as a predictor of treatment response in chronic schizophrenia. Psychiatry Res. 2011; 186(1): 23-7.

124.Medema S., Mocking R.J., Koeter M.W., Vaz F.M., Meijer C., de Haan L., van Beveren N.J.; GROUP;Genetic Risk and Outcome of Psychosis investigators, Kahn R., de Haan L., van Os J., Wiersma D., Bruggeman R., Cahn W., Meijer C., Myin-Germeys I. Levels of Red Blood Cell Fatty Acids in Patients With Psychosis, Their Unaffected Siblings, and Healthy Controls. Schizophr Bull. 2016; 42(2): 358-68.

\section{Correspondence address}

Joanna Róg

Wydział Nauk o Żywieniu Człowieka i Konsumpcji, Szkoła Główna Gospodarstwa Wiejskiego w Warszawie e-mail: joanna.rog@tlen.pl

Otrzymano: 18.08 .2016

Zrecenzowano: 28.09.2016

Przyjęto do druku: 28.09.2016 